\title{
Adaptability and stability in commercial maize hybrids in the southeast of the State of Minas Gerais, Brazil ${ }^{1}$
}

\author{
Adaptabilidade e estabilidade de híbridos comerciais de milho no sudeste de Minas \\ Gerais
}

\author{
Sirlene Viana Faria², Luiz Silva Luz ${ }^{3}$, Mateus Cupertino Rodrigues³, José Eustáquio de Souza Carneiro³, \\ Pedro Crescêncio Souza Carneiro ${ }^{4}$ and Rodrigo Oliveira DeLima ${ }^{3 *}$
}

\begin{abstract}
The aim of this study was to evaluate the adaptability and stability of 29 commercial maize hybrids in the southeast of the State of Minas Gerais, Brazil, employing three methods. The 29 commercial maize hybrids from the 2014/2015 crop were evaluated for grain yield in five locations in the southeast of Minas Gerais. A randomised-block design was used, with two replications. Each lot comprised two rows, five meters in length, at a spacing of $0.80 \mathrm{~m}$, giving an effective area of $8.00 \mathrm{~m} 2$. In addition to individual and combined variance analysis, the methods of Eberhart \& Russell (1966), AMMI (Additive Main Effects and Multiplicative Interaction Analysis) and mixed models were used to evaluate the adaptability and stability of the 29 hybrids. There was a significant difference $(\mathrm{P}<0.01)$ for the effects of hybrid, environment and the hybrid $\mathrm{x}$ environment interaction. The majority of the hybrids under evaluation displayed broad adaptability with good stability. It was concluded that the Eberhart \& Russell, AMMI and mixed-model methods show similar results in classifying maize hybrids of broad adaptability. There is a difference in indicating hybrids with specific adaptability to favourable and unfavourable environments. Based on the three methods, the hybrids SHS7920PRO, BM709PRO2, BRS1055 and BM650PRO2 show a general adaptability for the environments under evaluation.
\end{abstract}

Key words: Zea mays L.. Genotype x environment interaction. Hybrid recommendation.

RESUMO - O objetivo deste trabalho foi avaliar a adaptabilidade e estabilidade de 29 híbridos comerciais de milho, no sudeste de Minas Gerais, com emprego de três metodologias. Os 29 híbridos comercias de milho foram avaliados para produtividade de grãos, em cinco locais do sudeste de Minas Gerais, na safra 2014/2015. Utilizou-se o delineamento em blocos ao acaso com duas repetições. Cada parcela foi constituída de duas linhas de cinco metros de comprimento, espaçadas em $0,80 \mathrm{~m}$ com área útil de $8,00 \mathrm{~m}^{2}$. Além das análises de variâncias individual e conjunta, empregou-se os métodos de Eberhart \& Russell (1966), AMMI (Additive Main Effects and Multiplicative Interaction Analysis) e modelos mistos para avaliar a adaptabilidade e estabilidade dos 29 híbridos. Houve diferença significativa $(\mathrm{P}<0,01)$ para os efeitos de híbridos, ambientes e interação híbridos x ambientes. A maioria dos híbridos avaliados apresentou ampla adaptabilidade e boa estabilidade. Conclui-se que as metodologias de Eberhart \& Russell, AMMI e modelos mistos, apresentam resultados semelhantes na classificação de híbridos de milho com ampla adaptabilidade; há divergência na indicação de híbridos com adaptabilidade específica a ambientes favoráveis e desfavoráveis e; com base nas três metodologias, os híbridos SHS7920PRO, BM709PRO2, BRS1055 e o BM650PRO2 apresentam adaptabilidade geral nos ambientes avaliados.

Palavras-chave: Zea mays L.. Interação genótipos x ambientes. Recomendação de híbridos.

\footnotetext{
DOI: $10.5935 / 1806-6690.20170040$

*Autor para correspondencia

Recebido para publicação em 16/03/2016; aprovado em 30/06/2016

${ }^{1}$ Parte da Dissertação de Mestrado do primeiro autor apresentada ao Programa de Pós-Graduação em Genética e Melhoramento, Universidade Federal de Viçosa/UFV

${ }^{2}$ Universidade Federal de Viçosa/UFV, Minas Gerais-MG, Brasil, sirlene.faria@ufv.br

${ }^{3}$ Departamento de Fitotecnia, Universidade Federal de Viçosa/UFV, luiz.s.luz@ufv.br, mateusagroufv1987@gmail.com, jesc@ufv.br, rodrigoodelima@ ufv.br

${ }^{4}$ Departamento de Biologia Geral, Universidade Federal de Viçosa/UFV, Brasil, carneiro@ufv.br
} 


\section{INTRODUCTION}

Maize (Zea mays L.) is grown almost all over Brazil, in a wide variety of environments, using different production systems and levels of technology (MALDANER et al., 2014). The identification of genotypes with high production potential and with broad adaptability and stability is one of the principle target of maize breeding programs. This is why, before being released and recommended to farmers, hybrids are evaluated in many locations. However, cultivars evaluated in different environments may display different behaviour due to environmental variations, which would characterise the interaction between genotype and environment (HALDANE, 1946). Studying adaptability and stability is an alternative for reducing the effects of this interaction, and makes it possible to identify cultivars which have predictable behaviour, and which are responsive to environmental improvements (CRUZ; CARNEIRO; REGAZZI, 2014).

Different methods have been proposed to study the adaptability and stability of maize cultivars. Among these is the method proposed by Eberhart and Russell (1966), based on linear regression analysis, which among its advantages includes ease of application and interpretation of results. The recommendation of maize cultivars based on this method has been successfully employed by several authors (CARGNELUTTI FILHO et al, 2009; MIRANDA et al, 2009; OLIVEIRA; MOREIRA; FERREIRA, 2013; RIOS et al., 2009; SCAPIM et al., 2010), and recently, Carvalho et al. (2014) used this method to study the adaptability and stability of 16 maize genotypes in the state of Tocantins, and classify them as to production objective: either grain or green weight.

Among recent methods is AMMI analysis (Additive Main Effects and Multiplicative Interaction) (GAUCH; ZOBEL, 1996). It allows a more detailed evaluation of the genotype $\mathrm{x}$ environment interaction, and enables easy graphical interpretation of the results. The application of this analysis to evaluating maize cultivars can be found in the work of Balestre et al. (2009), Cargnelutti Filho et al. (2009) and Miranda et al. (2009). According to these last authors, the AMMI method is relatively simple, making it possible to study the phenotypic stability and genotypic behaviour of cultivars, as well as inferring the degree of divergence between the cultivars under evaluation.

In addition to these two methods, the method of mixed models has been used in recommending cultivars of various crops: carrots (SILVA et al., 2011), coffee (ROCHA et al., 2015) and beans (TORRES et al., 2015), as it displays some advantages over traditional methods
(RESENDE, 2007). The method considers the errors correlated within locations, provides genetic values already discounting instability, and allows selection by three attributes at one time (productivity, stability and adaptability). Mendes et al. (2012) employed this method to evaluate 45 varieties of maize in 49 environments. The authors concluded that, due to the characteristics of the method, it was suitable for use in maize breeding programs.

Traditional methods for the study of adaptability and stability have been used with success in the recommendation of maize cultivars. However, work employing more modern methods, such as AMMI and mixed models, in the evaluation of maize hybrids are scarce, and need further study. Thus, the objective of this study is to evaluate the adaptability and stability of 29 commercial maize hybrids in the southeast of the State of Minas Gerais (MG), employing the methods of Eberhart and Russell (1966), AMMI and mixed models.

\section{MATERIAL AND METHODS}

For this study, twenty-nine commercial maize hybrids released by different seed companies were evaluated in five environments in the southeast of Minas Gerais in the 2014/2015 season (Table 1): The Experimental Station of Coimbra, in the town of Coimbra, MG (2049'46.5' S, 4245'51.1' W, altitude $715 \mathrm{~m})$; The Diogo Alves de Mello Experimental Station, in Viçosa, MG (2046'04” S, 4252'10” W, altitude $662 \mathrm{~m}$ ) (Viçosa1); The Horta Nova Experimental Station (2045'47.6" S, 4249'25.1" W, altitude $665 \mathrm{~m}$ ), located in the district of São José do Triunfo, Viçosa, MG (Viçosa2); The Experimental Station of Embrapa Milho

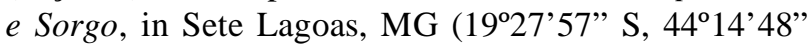
$\mathrm{W}$, altitude $761 \mathrm{~m}$ ), and in São Miguel do Anta, MG (2042'22.6" S, 4243'09.4”' W, altitude $661 \mathrm{~m}$ ).

The experimental design was of randomised blocks with two replications. Each plot consisted of two rows, five meters in length, spaced $0.80 \mathrm{~m}$ apart, with an effective area of $8.00 \mathrm{~m}^{2}$. When more than $50 \%$ of the plots had reached the V4 stage (four fully developed leaves), thinning was carried out in order to obtain a final population of 62,500 plants $\mathrm{ha}^{-1}$.

In São Miguel do Anta and the Diogo Alves de Mello Experimental Station (Viçosa), planting was carried out in December 2014 under a conventional system with the area prepared by ploughing and harrowing. In the remaining areas, planting was in December of the same year under a no-till system with prior desiccation of the vegetation using glyphosate. In all locations, sowing was 
Table 1 - Agronomic characteristics of 29 commercial maize hybrids evaluated for five environments in the southeast of Minas Gerais in the 2014/2015 season

\begin{tabular}{|c|c|c|c|c|}
\hline Hybrids & Type & Cycle & Company & Area of Adaptation \\
\hline DKB330PRO & $\mathrm{SC}$ & $\mathrm{EE}$ & Dekalb & $\mathrm{S}, \mathrm{CW}, \mathrm{SE}, \mathrm{NE}$ and RO \\
\hline BM915PRO & $\mathrm{SC}$ & $\mathrm{EE}$ & Biomatrix & SE, CW, N, S and PR \\
\hline AG7098PRO2 & $\mathrm{SC}$ & $\mathrm{E}$ & Agroceres & CW, SE, NE and PR, RO, TO \\
\hline DKB390 & $\mathrm{SC}$ & $\mathrm{E}$ & Dekalb & S, CW, SE, NE, RO, AC \\
\hline P3862H & $\mathrm{SC}$ & $\mathrm{E}$ & Du Pont do Brasil & S, SE, CW and BA, TO, PI, MA \\
\hline $30 \mathrm{~F} 35$ & $\mathrm{SC}$ & $\mathrm{E}$ & Du Pont do Brasil & $\mathrm{S}, \mathrm{SE}, \mathrm{CW}, \mathrm{NE}$ and TO, RO, RR, AC \\
\hline 2B587PW & $\mathrm{SC}$ & $\mathrm{E}$ & Dow Agrosciences & Brazil \\
\hline 2B710PW & $\mathrm{SC}$ & $\mathrm{E}$ & Dow Agrosciences & Brazil \\
\hline 30A16PW & $\mathrm{SC}$ & $\mathrm{E}$ & Morgan Sementes & Subtropical and high tropical regions \\
\hline BRS1010 & $\mathrm{SC}$ & $\mathrm{E}$ & Embrapa & Brazil excl. RS and SC \\
\hline SHS7920PRO2 & $\mathrm{SC}$ & $\mathrm{E}$ & Santa Helena & $\mathrm{SE}, \mathrm{CW}, \mathrm{PR}, \mathrm{RS}$ \\
\hline BM3066PRO2 & $\mathrm{SC}$ & $\mathrm{E}$ & Biomatrix & $\mathrm{S}, \mathrm{SE}$ \\
\hline BM820 & $\mathrm{SC}$ & $\mathrm{E}$ & Biomatrix & SE and CW \\
\hline BM840PRO & $\mathrm{SC}$ & $\mathrm{E}$ & Biomatrix & SE and CW \\
\hline RB9004PRO & $\mathrm{SC}$ & $\mathrm{E}$ & Riber KWS & $\mathrm{SE}, \mathrm{S}, \mathrm{NE}, \mathrm{CW}, \mathrm{N}$ \\
\hline BM650PRO2 & $\mathrm{SC}$ & SME & Biomatrix & $\mathrm{SE}, \mathrm{CW}$ \\
\hline BM709PRO2 & $\mathrm{SC}$ & SME & Biomatrix & $\mathrm{S}, \mathrm{SE}, \mathrm{CW}$ \\
\hline BRS1055 & $\mathrm{SC}$ & SME & Embrapa & NE, SE, CW, N, PR \\
\hline 2B810PW & $\mathrm{SC}$ & $\mathrm{N}$ & Dow Agrosciences & Tropical and other regions \\
\hline BRS3035 & $\mathrm{TC}$ & $\mathrm{EE}$ & Embrapa & CW, NE, SE and PR \\
\hline 20A55PW & $\mathrm{TC}$ & $\mathrm{E}$ & Morgan Sementes & Brazil \\
\hline BM3063 & $\mathrm{TC}$ & $\mathrm{E}$ & Biomatrix & $\mathrm{S}, \mathrm{SE}, \mathrm{CW}, \mathrm{NE}, \mathrm{N}$ \\
\hline BG7049H & $\mathrm{TC}$ & $\mathrm{E}$ & Du Pont do Brasil & S, SE, CW and BA, TO, PI, MA \\
\hline 2B512PW & $\mathrm{TC}$ & $\mathrm{E}$ & Dow Agrosciences & Brazil \\
\hline BRS3060 & $\mathrm{TC}$ & SME & Embrapa & $\mathrm{SE}, \mathrm{CW}$ and MA, TO \\
\hline BM207 & $\mathrm{DC}$ & $\mathrm{E}$ & Biomatrix & $\mathrm{S}, \mathrm{SE}, \mathrm{CW}, \mathrm{NE}, \mathrm{N}$ \\
\hline CARGO & $\mathrm{DC}$ & $\mathrm{E}$ & Syngenta & $\mathrm{S}, \mathrm{CW}, \mathrm{SE}$ \\
\hline FEROZViptera & $\mathrm{DC}$ & $\mathrm{E}$ & Syngenta & $\mathrm{S}, \mathrm{CW}, \mathrm{SE}$ and BA, MA, PI \\
\hline AS1573PRO & MSC & $\mathrm{E}$ & Agroeste & $\mathrm{S}$ and $\mathrm{SP}, \mathrm{MG}, \mathrm{MS}$ \\
\hline
\end{tabular}

Type: SC - Single cross; TC - Triple-way cross; DC - Double cross; MSC - Modified Single cross. Cycle: EE - Extra-Early; E - Early; SME - Semi-Early; N Normal. Area: S - South; CW - Central West; SE - Southeast; NE- Northeast; N - North; PR - Paraná; RO - Rondônia; TO - Tocantins; AC - Acre; BA - Bahia; PI - Piauí; MA - Maranhão; RR - Roraima; RS - Rio Grande do Sul; SC - Santa Catarina; SP- São Paulo; MG - Minas Gerais; MS - Mato Grosso do Sul

done manually. Management and treatment were carried out in accordance with the technical recommendations for maize crops (CRUZ et al., 2008). When planting, $400 \mathrm{~kg} \mathrm{ha}^{-1}$ of 08-28-16 formulation NPK fertiliser was applied. Later, at the V6 stage (six fully developed leaves) a topdressing of $150 \mathrm{~kg} \mathrm{~N} \mathrm{ha}^{-1}$ was applied in the form of urea. Grain yield was evaluated, weighing the grain from each lot corrected for $14.5 \%$ moisture, with the values converted to $\mathrm{kg} \mathrm{ha}^{-1}$.
After collecting the data, analysis of variance was performed for each environment to analyse the existence of genotypic variability among the maize hybrids, and a combined analysis of variance, with the aim of detecting the genotype $x$ environment interaction. Before performing the combined analysis of variance, the homogeneity of the residual variances was tested to carry out environmental clustering. (PIMENTEL-GOMES, 2000). Later, an analysis of adaptability and stability was performed using 
the Eberhart and Russell (1966), AMMI and mixed-model REM/BLUP methods. In the evaluation of individual genotypes, the Eberhart and Russell method (1966) uses the average productivity $\left(\beta_{o i}\right)$, the regression coefficient $\left(\beta_{1 i}\right)$ of each genotype in relation to the environmental index, and the variation in deviation of this regression $\left(\sigma_{\mathrm{di}}^{2}\right)$. In using this method, the following regression model (Equation 1) was employed:

$y_{i j}=\beta_{o i}+\beta_{l i} I_{j}+\delta_{i j+} \varepsilon_{\mathrm{ij}}$

where: $\mathrm{y}_{i j}$ is the mean value of genotype $i$, in environment $j ; \beta_{o i}$ is the constant of the regression and represents the overall mean value for genotype $i ; \beta_{1 i}$ is the linear regression coefficient which measures the response of the $i$-th genotype to variation in the environment; $I_{j}$ is the encoded environmental index; $\delta_{i j}$ is the deviation of regression; and $\varepsilon_{\mathrm{ij}}$ is the mean experimental error.

For the AMMI analysis (GAUCH; ZOBEL, 1997), which combines into a single model additive components for the main effects of the genotypes and environments, and multiplicative components for the interaction effects, the following model was used:

$\mathrm{y}_{\mathrm{ij}}=\mu+\mathrm{g}_{\mathrm{i}}+\mathrm{a}_{\mathrm{j}}+\sum_{\mathrm{k}=1}^{\mathrm{n}} \lambda_{\mathrm{k}} \gamma_{\mathrm{ik}} \alpha_{\mathrm{jk}}+\rho_{j k}+\varepsilon_{\mathrm{ij}}$

where: $y_{i j}$ is the average productivity of genotype $i(\mathrm{i}=1,2$, $\ldots, 29)$ in environment $j(\mathrm{j}=1,2, \ldots, 5) ; \mu$ is the overall mean value of the experiments; $g_{i}$ is the fixed effect of genotype $i$; $a_{j}$ is the effect of environment $j ; \lambda_{k}$ is the $k$-th single value of the interaction matrix; $\gamma_{i k}$ is the element corresponding to the $i$-th genotype in the $k$-th single vector column of matrix $\mathrm{GA} ; \alpha_{j k}$ is the element corresponding to the $j$-th environment, in the $k$-th single vector line of matrix GA; $\rho_{j k}$ is the residual associated with the term for the classic interaction of genotype $i$ with environment $j ; \varepsilon_{\mathrm{ij}}$ is the mean experimental error associated with the observation, assuming $\varepsilon \sim \mathrm{N}\left(0, \sigma^{2}\right)$ as independent; and $n$ is the number of axes or retained main components for describing the pattern of the genotype $\mathrm{x}$ environment interaction.

For the mixed-model method, model 54 of the SELEGEN REML/BLUP software was used (RESENDE, 2007):

$y=X r+Z g+W i+e$,

where: $y$ is the data vector; $r$ is the vector of fixed repetition effects added to the overall mean value; $g$ is the vector of random genotypic effects; $i$ is the vector of the random effects from the genotype $\mathrm{x}$ environment interaction; $e$ is the random error vector; and $\mathrm{X}, \mathrm{Z}$ and $\mathrm{W}$ are the incidence matrices for $b, g$ and $c$ respectively.

The joint selection, taking productivity, stability and adaptability of the maize genotypes together, was obtained from the harmonic mean of the relative performance of the predicted genotypic values:

$$
M H P R V G_{i}=n / \sum_{i=1 \frac{1}{P R V G_{i j}}}^{j}
$$

where: $n$ is the number of environments; $P_{R V G}=V_{i j} G_{i j} /$ $V_{\mathrm{j}}$, where: $\mathrm{VG}_{\mathrm{ij}}$ is the genetic value of genotype $i$ in environment $j$; and $\mathrm{VG}_{\mathrm{j}}$ corresponds to the genotypic mean in environment $j$.

To facilitate interpretation of the results, the MHPRVG values were multiplied by the overall mean value, giving results of the same magnitude as the characteristic being studied. Later, the environments were grouped into favourable and unfavourable, according to the overall mean of the hybrids in all of the environments, and separate analyses were carried out for each environment group. Environments where the average value was higher than the overall average were considered favourable, and those where the average value was less than the overall average were considered unfavourable. This resulted in the creation of new values for MHPRVG for each environment group, which were compared using dispersion diagrams.

The genetic and statistical analyses were carried out with the help of the Genes (CRUZ, 2013), the SELEGEN (RESENDE, 2007) and the R Statistical Software (R Development Core Team, 2010).

\section{RESULTS AND DISCUSSION}

With the results of the individual analysis of variance, a significant difference $(\mathrm{P}<0.05)$ was found between the hybrid averages for grain yield at all the sites under evaluation (data not shown). Accuracy values ranged from 0.75 to 0.89 , indicating the high precision of the experiments (RESENDE; DUARTE, 2007). Furthermore, it was found that the ratio between the largest and smallest residual mean square was less than 7.0 (2.8), which indicates homogeneity of the residual variances. This made it possible to carry out combined analysis (Table 2), which showed a significant effect $(\mathrm{P}<0.01)$ for all the tested sources of variation. The significant hybrid $\mathrm{x}$ environment interaction demonstrates that the hybrids had different responses in relation to the environmental changes. In the work of Balestre et al. (2009) and Miranda et al. (2009), different responses were also seen for grain yield in commercial maize hybrids when grown in different environments.

The average grain yield of the hybrids in the environments ranged from $3,163 \mathrm{~kg} \mathrm{ha}^{-1}$ in São Miguel do Anta to $12,399 \mathrm{~kg} \mathrm{ha}^{-1}$ in Sete Lagoas, with an overall 
Table 2 - Summary of the combined analysis of variance for grain yield evaluated in 29 commercial maize hybrids for five environments in Minas Gerais, in the 2014/2015 season

\begin{tabular}{lcrr}
\hline \multicolumn{1}{c}{ SV } & DOF & Mean Square & F \\
\hline Block/Environment & 5 & 3099720.87 & $3.34 * *$ \\
Hybrids & 28 & 13735535.84 & $249.38^{* *}$ \\
Environments & 4 & 773004952.01 & $2.34 * *$ \\
Hybrids x Environments & 112 & 4114515.85 & \\
Error & 140 & 1756850.52 & 9146.26 \\
\hline Mean & & 14.49 & 0.76 \\
CV $(\%)$ & & & \\
Accuracy & & & \\
\hline
\end{tabular}

**: significant at $1 \%$ probability by F-test

average of $9,146 \mathrm{~kg} \mathrm{ha}^{-1}$. This average was higher than the national average of $5,411 \mathrm{~kg} \mathrm{ha}^{-1}$, obtained in the last harvest (CONAB, 2016). The coefficient of variation $(\mathrm{CV})$, which measures experimental accuracy, was $14.49 \%$, classified as average for the productivity of maize grain (FRITSCHE-NETO et al., 2012) and indicating good experimental precision. In similar studies with maize, the value for the coefficient of variation ranged from 10.66\% (CARGNELUTTI FILHO et al., 2009) to $22.0 \%$ (CARDOSO et al., 2012) for the characteristic of grain yield. Such satisfactory precision was confirmed by the high value for accuracy (0.76) obtained with the combined analysis (RESENDE; DUARTE, 2007).

According to the Eberhart and Russell method (1966), two environments were classified as unfavourable - Coimbra and São Miguel do Anta. These environments showed negative values for $I_{j}$, which are usually associated with areas of adverse weather or soil conditions, or areas with low levels of technology and little input. The environments at Viçosa1, Viçosa2 and Sete Lagoas were classified as favourable, and were where the hybrids had the highest grain yields.

When analysing the parameters of adaptability and stability by the Eberhart and Russell method (1966) (Table 3), it can be seen that $89.66 \%$ of the hybrids had regression coefficients statistically equal to one $(\beta 1 \mathrm{i}=1)$ and were classified as having general adaptability. The $\mathrm{P} 3862 \mathrm{H}$ and AG7098PRO2 hybrids were classified as having specific adaptability to favourable environments $\left(\beta_{1 i}>1\right)$, i.e. according to this method, these hybrids responded favourably to improvements in the environment. The CARGO hybrid had a value for $\beta_{1 \mathrm{i}}$ statistically less than one $\left(\beta_{1 \mathrm{i}}<1\right)$, which demonstrates the adaptability of this hybrid to unfavourable environments; it displayed no increase in grain yield with improvements in the environment, and should be recommended for areas of low investment and low levels of technology.
For phenotypic stability, $59 \%$ of the hybrids showed a deviation of regression equal to zero $\left(\sigma^{2}{ }_{\mathrm{di}}=\right.$ 0 ), which indicates the high behavioural predictability of these hybrids. In contrast, the hybrids RB9004PRO, 30A16PW, BM3063, BM3066PRO2, DKB390, 2B810PW,BM840PRO,30F35,20A55PW,AS1573PRO, BM915PRO and DKB330PRO showed significant deviation of regression $\left(\sigma_{\mathrm{di}}^{2} \neq 0\right)$, demonstrating their unpredictable behaviour in the environments. These are single hybrids, with the exception of BM3063 (TC) and 20A55PW (TC), and have a constitution of low genetic stability, as they result from the crossing of only two lines (HALLAUER; MIRANDA FILHO; CARENA, 2010). However, such results should not limit the use of these hybrids because, with the exception of hybrids RB9004PRO, 30F35, 20A55PW, AS1573PRO, BM915PRO and DKB330PRO, they had values for the coefficient of determination $\left(\mathrm{R}^{2}\right)$ of over $85 \%$, which is recommended for maize (OLIVEIRA; MOREIRA; FERREIRA, 2013). This coefficient is an auxiliary measure of comparison between genotypes, and reflects the goodness of fit of the model to the yields observed in each of the hybrids under evaluation. These results showed that a large part of the variations was explained by the adopted model.

In the simultaneous analysis of the parameters of adaptability and stability $\left(\beta_{1 \mathrm{i}}\right.$ and $\left.\sigma_{\mathrm{di}}^{2}\right)$, obtained with the Eberhart and Russell method (1966), it is found that most hybrids showed high behavioural predictability and broad adaptability. The hybrids SHS7920PRO, 30A16PW, BM709PRO2, BRS1055, FEROZViptera, BM650PRO2, BM3063, BG7049Hx, BM3066PRO2, DKB390, 2B587PW, 2B512PW and 2B810PW are noteworthy, as together with these parameters they had grain yields higher than the overall average $\left(9,146 \mathrm{~kg} \mathrm{ha}^{-1}\right)$. Furthermore, they had values for the coefficient of determination $\left(\mathrm{R}^{2}\right)$ greater than $85 \%$. 
Table 3 - Estimates of the parameters of adaptability and stability according to the Eberhart and Russell method (1966), for the 29 maize hybrids evaluated for five environments in Minas Gerais, in the 2014/2015 season

\begin{tabular}{|c|c|c|c|c|c|}
\hline Cultivar & Type & Mean $\left(\beta_{0}\right)$ & $\beta_{1}$ & $\sigma_{d}^{2}$ & $\mathrm{R}^{2}(\%)$ \\
\hline RB9004PRO & $\mathrm{SC}$ & 11229 & $1.09^{\mathrm{ns}}$ & $3133101.76^{++}$ & 83.89 \\
\hline SHS7920PRO & $\mathrm{SC}$ & 10916 & $0.86^{\mathrm{ns}}$ & $69960.81^{\mathrm{ns}}$ & 93.02 \\
\hline BM709PRO2 & $\mathrm{SC}$ & 10842 & $1.05^{\mathrm{ns}}$ & $25344.87^{\mathrm{ns}}$ & 95.50 \\
\hline 30A16PW & SC & 10538 & $1.04^{\mathrm{ns}}$ & $2308096.55^{+}$ & 85.62 \\
\hline BRS1055 & $\mathrm{SC}$ & 10413 & $1.15^{\mathrm{ns}}$ & $-429872.25^{\mathrm{ns}}$ & 98.03 \\
\hline P3862H & SC & 10237 & $1.31 *$ & $-597268.58^{\mathrm{ns}}$ & 98.99 \\
\hline AG7098PRO2 & SC & 10198 & $1.26^{*}$ & $-677647.70^{\mathrm{ns}}$ & 99.20 \\
\hline FEROZViptera & $\mathrm{DC}$ & 9846 & $0.98^{\mathrm{ns}}$ & $9315.50^{\mathrm{ns}}$ & 94.90 \\
\hline BM650PRO2 & SC & 9642 & $1.03^{\mathrm{ns}}$ & $-636357.08^{\mathrm{ns}}$ & 98.58 \\
\hline BM3063 & $\mathrm{TC}$ & 9615 & $0.99^{\mathrm{ns}}$ & $1668130.38^{+}$ & 87.06 \\
\hline BG7049Hx & $\mathrm{TC}$ & 9613 & $1.14^{\mathrm{ns}}$ & $-383313.48^{\mathrm{ns}}$ & 97.80 \\
\hline BM3066PRO2 & SC & 9570 & $1.22^{\mathrm{ns}}$ & $3259669.73^{++}$ & 86.38 \\
\hline DKB390 & SC & 9440 & $1.02^{\mathrm{ns}}$ & $1825831.31^{+}$ & 87.19 \\
\hline 2B587PW & SC & 9424 & $0.97^{\mathrm{ns}}$ & $551689.11^{\text {ns }}$ & 91.95 \\
\hline 2B512PW & $\mathrm{TC}$ & 9336 & $0.81^{\mathrm{ns}}$ & $-165955.72^{\mathrm{ns}}$ & 94.08 \\
\hline 2B810PW & SC & 9257 & $1.12^{\mathrm{ns}}$ & $2304586.26^{+}$ & 87.41 \\
\hline BM840PRO & SC & 9170 & $1.12^{\mathrm{ns}}$ & $1678390.30^{+}$ & 89.64 \\
\hline 30F35 & SC & 9089 & $1.01^{\mathrm{ns}}$ & $4149347.19^{++}$ & 78.27 \\
\hline 20A55PW & $\mathrm{TC}$ & 8854 & $0.81^{\mathrm{ns}}$ & $5334493.04^{++}$ & 65.01 \\
\hline AS1573PRO & MSC & 8629 & $0.82^{\mathrm{ns}}$ & $4744433.27^{++}$ & 67.86 \\
\hline 2B710PW & $\mathrm{SC}$ & 8522 & $0.88^{\mathrm{ns}}$ & $-766126.79^{\mathrm{ns}}$ & 98.99 \\
\hline BRS3035 & $\mathrm{TC}$ & 8183 & $0.85^{\mathrm{ns}}$ & $121582.74^{\mathrm{ns}}$ & 92.58 \\
\hline BM820 & SC & 7835 & $1.16^{\mathrm{ns}}$ & $-461560.46^{\mathrm{ns}}$ & 98.18 \\
\hline BM207 & $\mathrm{DC}$ & 7810 & $1.06^{\mathrm{ns}}$ & $362942.76^{\mathrm{ns}}$ & 94.04 \\
\hline BRS3060 & $\mathrm{TC}$ & 7709 & $0.81^{\mathrm{ns}}$ & $1301865.92^{\mathrm{ns}}$ & 84.23 \\
\hline CARGO & DC & 7640 & $0.65^{* *}$ & $-456417.02^{\mathrm{ns}}$ & 94.30 \\
\hline BM915PRO & $\mathrm{SC}$ & 7505 & $0.91^{\mathrm{ns}}$ & $4808234.22^{++}$ & 72.19 \\
\hline DKB330PRO & $\mathrm{SC}$ & 7253 & $1.06^{\mathrm{ns}}$ & $4966222.34^{++}$ & 77.21 \\
\hline BRS1010 & $\mathrm{SC}$ & 6929 & $0.82^{\mathrm{ns}}$ & $159466.08^{\mathrm{ns}}$ & 91.78 \\
\hline
\end{tabular}

${ }^{\text {nss }}$ not significant and $* *, *$ : significantly different to 1 by t-test at $1 \%$ and $5 \%$ probability respectively. ${ }^{++},{ }^{+}$: significantly different to 0 by $\mathrm{F}$-test at $1 \%$ and $5 \%$ probability respectively

In the AMMI analysis, the first two principal components (PC1 and PC2) explained $76.8 \%$ of the variation due to the hybrid $\mathrm{x}$ environment interaction. According to Silva et al. (2011), there is a greater capture of the percentage variation with the first few principal components, and as the number of selected axes increases, the percentage of "noise" also increases, reducing the predictive power of the analysis. There was $29 \%$ residual noise, reflecting the relevance of the graph. The graph was therefore interpreted employing only the biplot and the AMMI2 model. Evaluating maize hybrids in different environments in the State of Minas Gerais by AMMI analysis, Namorato et al. (2009) also used the AMMI2 model, as observation of the first two axes in that model ensured a better graphical display, however the model only captured $50.7 \%$ of the sum of squares of the genotype $\mathrm{x}$ environment interaction. 
Interpretation of stability by the AMMI method was based on the distance to zero of the scores of points representing the hybrids and environments (Figure 1). A shorter distance indicates greater stability (DUARTE; VENCOVSKY, 1999). The hybrids that are positioned closer to the origin of the axes are SHS7920PRO, BM709PRO2, BRS1055, P3862H, AG7098PRO2, BM650PRO2, BG7049Hx, 2B710PW, BM820 and BM207. These hybrids contributed little to the total hybrid $\mathrm{x}$ environment interaction, and were considered more stable and to be of general adaptability, as they interacted less with the environments. However, the 2B710PW, BM820 and BM207 hybrids were not the most productive. Of the 29 hybrids under evaluation, 19 contributed the most to the hybrid $\mathrm{x}$ environment interaction, as they are the most distant from the source of the biplot and are therefore more unstable. All the environments being evaluated are distant from the origin of the axes, and contribute to the total hybrid $\mathrm{x}$ environment interaction. The adaptability of the hybrids in each crop environment was interpreted by observing the signs of the hybrid and environment scores. In AMMI analysis, when the vector that represents the cultivar on the Cartesian plane is close to the vector that represents a particular environment, it shows that the cultivar performs better in that environment compared to the other cultivars (MIRANDA et al., 2009). When the hybrids and environments are distant from the origin and close to each other, with scores of the same sign, this represents specific adaptability. In this way, the hybrids 20A55PW, BM915PRO and 30A16PW stood out in the Viçosal and Sete Lagoas environments. These environments were considered favourable by the Eberhart and Russell method (1966). The hybrids DKB330PRO and AS1573PRO display specific adaptability to the environment of São Miguel do Anta, considered unfavourable by the Eberhart and Russell method (1966).

In estimating individual broad-sense heritability $\left(\mathrm{h}_{\mathrm{g}}^{2}\right)$ by the method of mixed models, total genetic dispersion is considered, which is relevant, since this research seeks to explore all the genetic variance between the hybrids (RESENDE; DUARTE, 2007). Estimated heritability was 0.70 , considered of moderate magnitude for grain yield in maize (HALLAUER, MIRANDA FILHO; CARENA, 2010) (Table 4). The selection of maize hybrids based on predicted genotypic values is therefore reliable (TORRES et al., 2015). The estimation of accuracy, which measures the correlation between predicted values and actual values, was also high at $83.69 \%$. It can therefore be inferred that the experimental precision was high (RESENDE, DUARTE, 2007), which

Figure 1 - AMMI biplot, with the first two principal components (PC1 and PC2) for grain yield (kg ha $\left.{ }^{-1}\right)$ evaluated in 29 commercial maize hybrids in the 2014/2015 season, for five environments in Minas Gerais

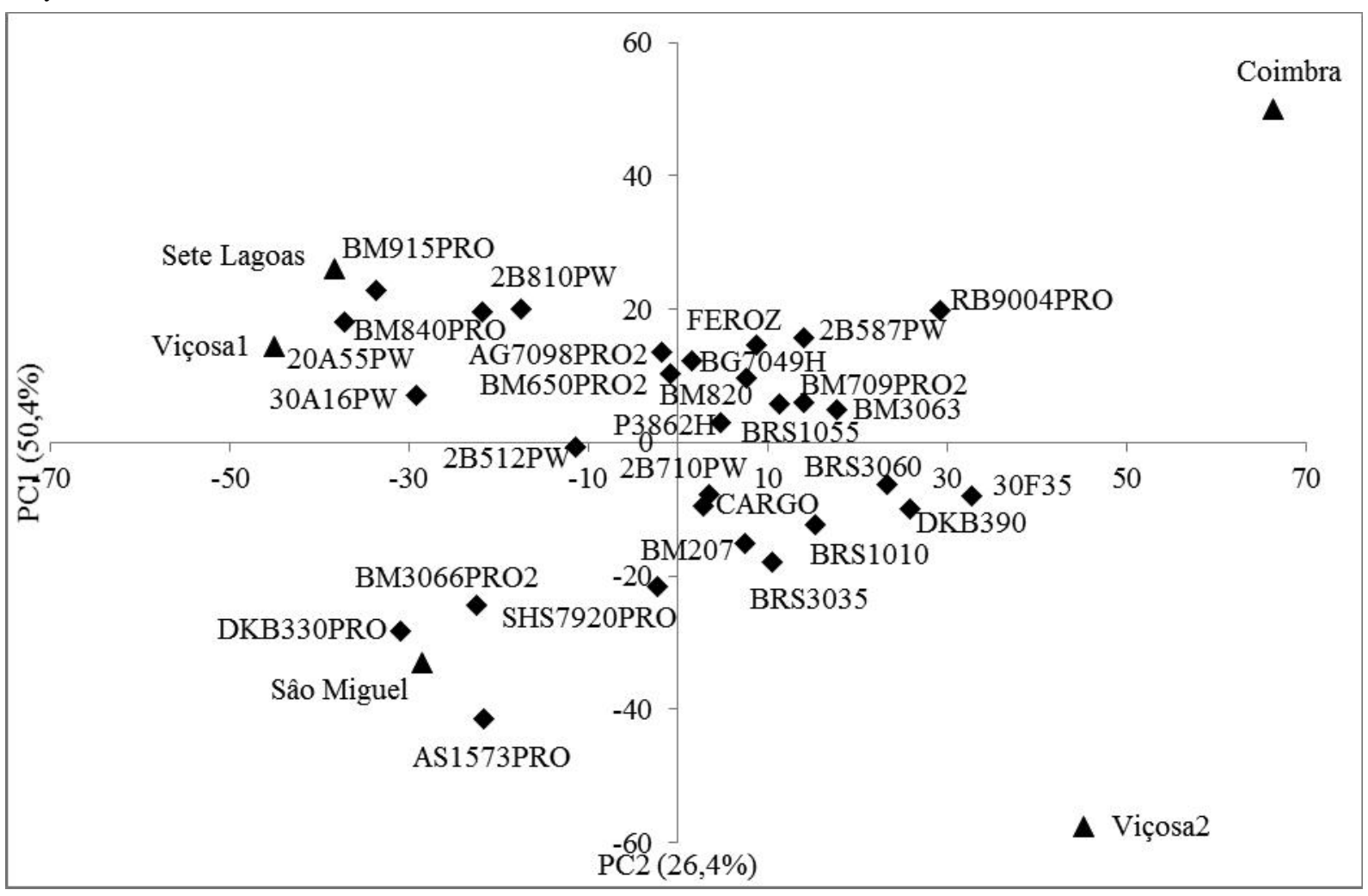


Table 4 - Estimates of the genetic parameters for grain yield $\left(\mathrm{kg} \mathrm{ha}^{-1}\right)$ obtained with the REML/BLUP method, estimated in 29 maize hybrids in the 2014/2015 season, for five locations in Minas Gerais

\begin{tabular}{lc}
\hline \multicolumn{1}{c}{ Parameter } & Estimate \\
\hline Heritability $\left(\mathrm{h}^{2}\right)$ & 0.70 \\
Accuracy & 0.84 \\
Genotypic correlation between environments & 0.45 \\
CVe $(\%)$ & 14.49 \\
Overall Mean $\left(\mathrm{kg} \mathrm{ha}^{-1}\right)$ & $9,146.26$ \\
\hline
\end{tabular}

agrees with the estimate of the experimental coefficient of variation $(\mathrm{CVe}=14.49 \%)$. Results of similar magnitudes were obtained by Mendes et al. (2012) when estimating genetic parameters in 45 varieties of maize by the REML/ BLUP method. Those authors found high experimental precision with a $\mathrm{CVe}$ of $13.6 \%$ and an estimated accuracy of $97 \%$. According to Resende (2007), experimental precision can be considered excellent in experiments with precision values greater than $90 \%$.

According to the confidence interval, the maize hybrids differed for grain yield, with hybrids RB9004PRO, SHS7920PRO, BM709PRO2, 30A16PW and BRS1055 displaying grain yields greater than $10,000 \mathrm{~kg} \mathrm{ha}^{-1}$ (Figure 2). All are single hybrids and recommended for production systems that employ high technology.

Figure 3 shows the results of the MHPRVG*GM measures of adaptability and stability, penalising the hybrids for instability through the environments and at the same time benefitting their response capacity to environmental improvement (RESENDE, 2007). Despite the significant hybrid $\mathrm{x}$ environment interaction, hybrids of good adaptability and production stability were found. Hybrid RB9004PRO had the best performance, with a MHPRVG*GM value of $11,078 \mathrm{~kg} \mathrm{ha}^{-1}$, followed by SHS7920PRO and BM709PRO2, with 11,067 and 10,821 $\mathrm{kg} \mathrm{ha}^{-1}$ respectively.

The MHPRVG method was also applied separately to the environments (Table 5). To this end, the five environments were divided into two groups, based on the average productivity of the hybrids in each location. The environments at Viçosa1, Viçosa 2 and Sete Lagoas, with an average grain yield greater than the overall average $\left(9,146 \mathrm{~kg} \mathrm{ha}^{-1}\right)$, were considered favourable, and Coimbra and São Miguel do Anta, with averages below this value, were considered unfavourable. Estimated heritability for grain yield was greater in the group of favourable environments (0.64) than in the group of unfavourable environments (0.12). This same trend was seen for estimated accuracy, 0.80 and 0.35 respectively. That is, favourable conditions provide greater experimental precision than unfavourable conditions. Average productivity was $11,407 \mathrm{~kg} \mathrm{ha}^{-1}$ for the favourable environments, and $5,755 \mathrm{~kg} \mathrm{ha}^{-1}$ for the unfavourable environments.

The hybrids SHS7920PRO, RB9004PRO, BM709PRO2, 30A16PW, FEROZViptera, BM650PRO2, BRS1055, BM3063 and DKB390 displayed a productivity greater than the overall average in both the favourable and unfavourable environments; these were classified as having high adaptability. The hybrids 2B512PW, 2B587PW and 20A55PW were classified as having specific adaptability to unfavourable environments. The hybrids with specific adaptability to favourable environments were 2B810PW, AG7098PRO2, BG7049Hx, P3862H, BM840PRO and $\mathrm{BM} 3066 \mathrm{PRO}$. The remaining hybrids did not achieve good performance in any of the environments, and were considered of minimal adaptability (Figure 4).

Figure 2 - Average genotypic values (VG) and their respective confidence intervals, for grain yield $\left(\mathrm{kg} \mathrm{ha}^{-1}\right)$ in 29 commercial maize hybrids evaluated for five environments in Minas Gerais, in the 2014/2015 season

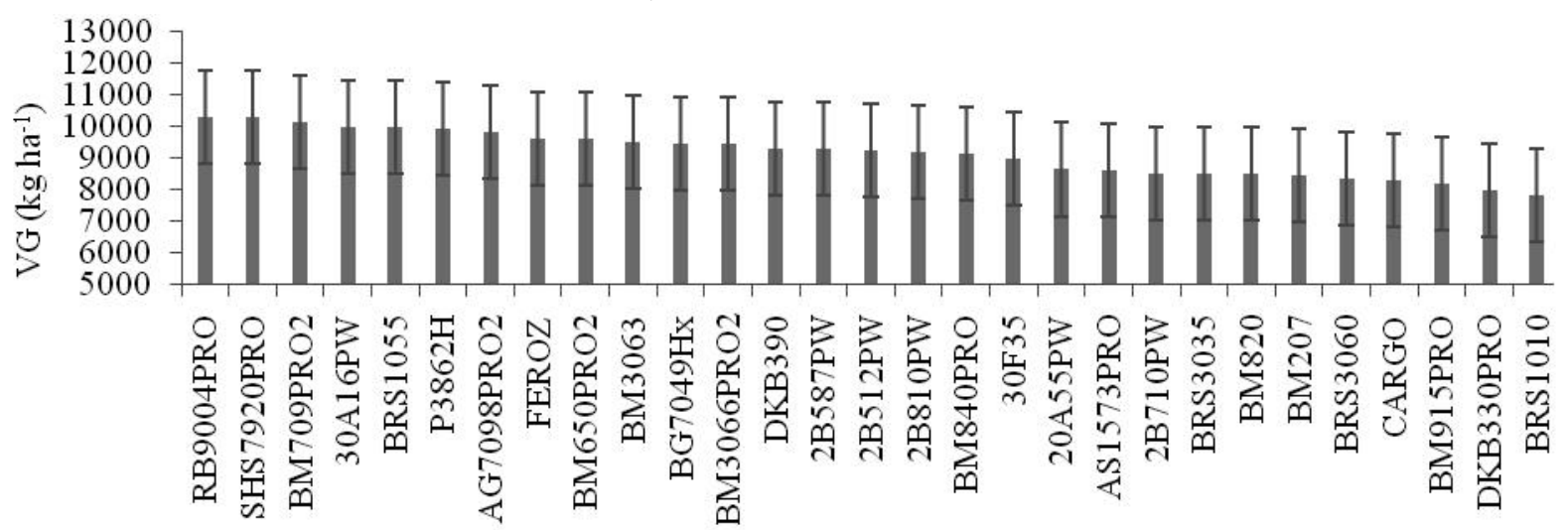


Figure 3 - Mean values for MHPRVG*GM in 29 commercial maize hybrids evaluated for grain yield $\left(\mathrm{kg} \mathrm{ha}^{-1}\right)$ for five environments in Minas Gerais, in the 2014/2015 season

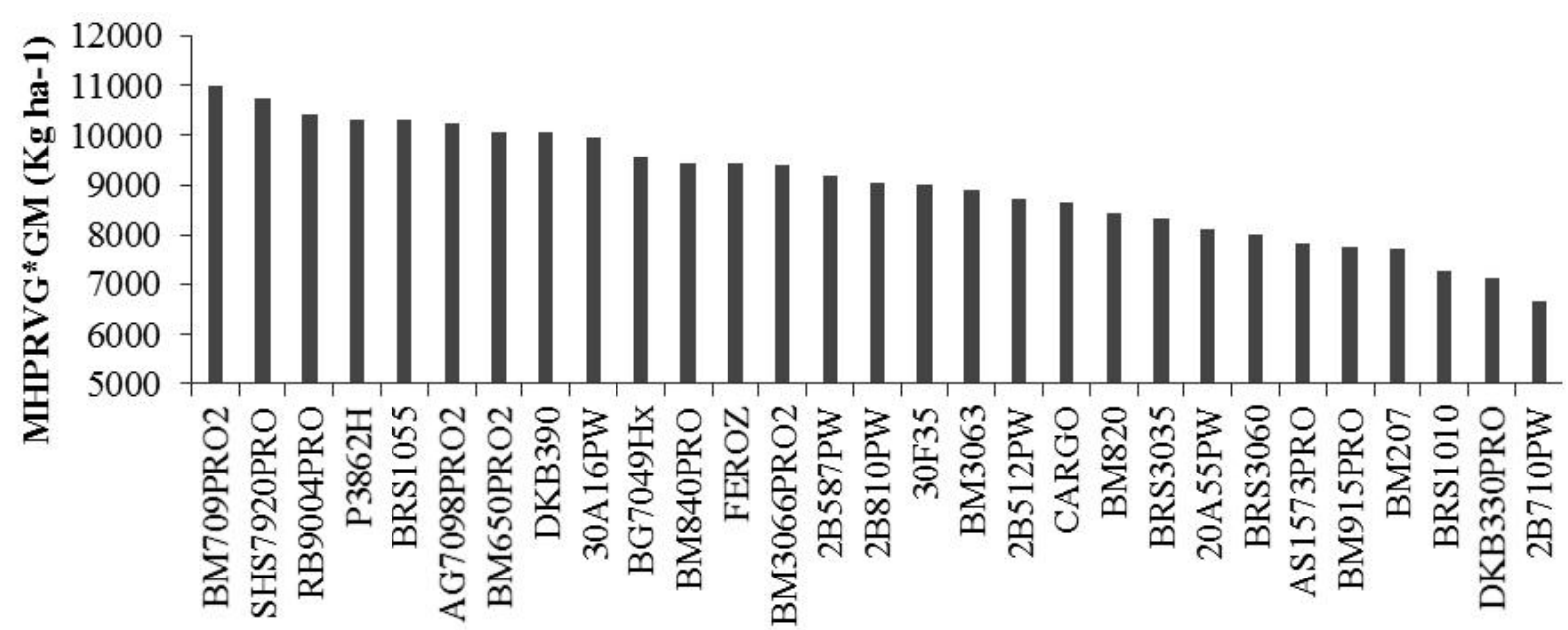

Table 5 - Estimates of the genetic parameters for grain yield $\left(\mathrm{kg} \mathrm{ha}^{-1}\right)$ in favourable and unfavourable environments

\begin{tabular}{lcc}
\hline \multicolumn{1}{c}{ Parameter } & Favourable environment & Unfavourable environment \\
\hline Heritability $\left(\mathrm{h}^{2}\right)$ & 0.64 & 0.12 \\
Accuracy & 0.80 & 0.35 \\
Genotypic correlation between environments & 0.49 & 0.10 \\
CVe $(\%)$ & 10.70 & 25.60 \\
Overall Mean $\left(\mathrm{kg} \mathrm{ha}^{-1}\right)$ & $11,406.93$ & $5,755.25$ \\
\hline
\end{tabular}

Figure 4 - Dispersion diagram of MHPRVG*GM for grain yield $\left(\mathrm{kg} \mathrm{ha}^{-1}\right)$ in 29 maize hybrids in favourable and unfavourable environments

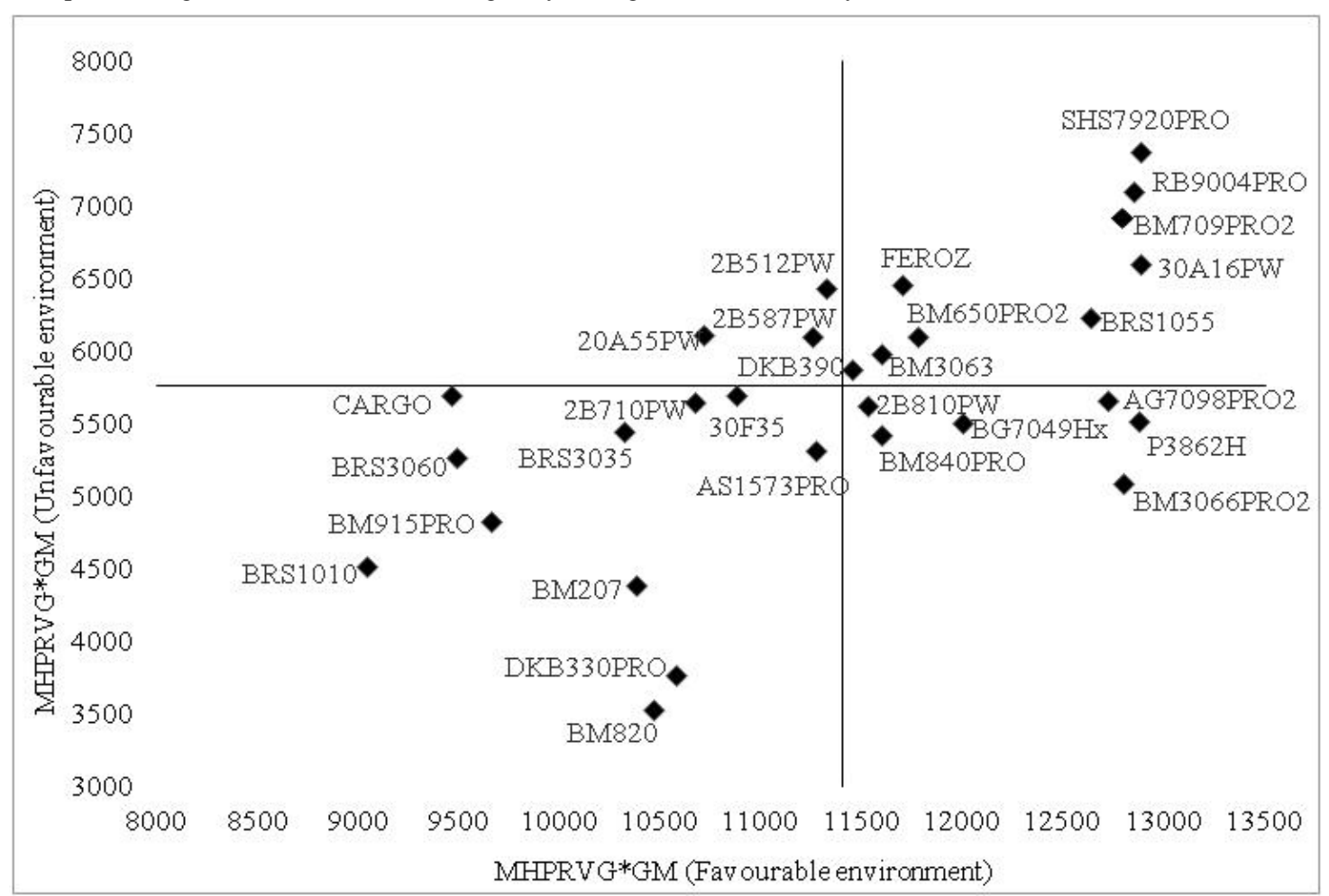


There were similarities seen in the three methods used for indicating hybrids. Among the most productive hybrids, stable and of broad adaptability, and recommended by the Eberhart and Russell method, SHS7920PRO, BM709PRO2, BRS1055 and BM650PRO2 were also indicated by the AMMI analysis and the REM/BLUP method. For favourable environments, the Eberhart and Russell and the mixedmodel REM/BLUP methods recommended the P3862H and AG7098PRO2 hybrids. According to the results, it can be seen that the use of more than one method to estimate genetic parameters is a strategy that allows for greater reliability in the interpretation of data for the subsequent recommendation of cultivars. For Cruz, Carneiro and Regazzi (2014), some methods are seen as alternatives, while others are complementary and can be used together.

\section{CONCLUSIONS}

1. The Eberhart and Russell, AMMI and mixed-model methods show similar results in classifying maize hybrids of broad adaptability;

2. There is a difference in the indication of hybrids of specific adaptability to favourable and unfavourable environments, which justifies the use of more than one method of evaluation;

3. Based on the three methods, the hybrids SHS7920PRO, BM709PRO2, BRS1055 and BM650PRO2 display general adaptability in the environments under evaluation; the hybrids $\mathrm{P} 3862 \mathrm{H}$ and AG7098PRO2 displayed specific adaptability to favourable environments.

\section{ACKNOWLEGMENTS}

We thank the Foundation for Research Support of Minas Gerais State (Fapemig), the Brazilian Federal Agency for Support and Evaluation of Graduate Education (Capes), and the National Council for Scientific and Technological Development (CNPq) for financial support.

\section{REFERENCES}

BALESTRE, M. et al. Yield stability and adaptability of maize hybrids based on GGE biplot analysis characteristics. Crop Breeding and Applied Biotechnology, v. 9, p. 219228, 2009.
CARGNELUTTI FILHO et al. Associação entre métodos de adaptabilidade e estabilidade em milho. Ciência Rural, v. 39, p. $340-347,2009$.

CARDOSO, M. J. et al. Identificação de cultivares de milho com base na análise de estabilidade fenotípica no Meio-Norte brasileiro. Revista Ciência Agronômica, v. 43, n. 2, p. 346-353, 2012.

CARVALHO, E. V. et al. Adaptabilidade na produção de massa verde e grãos de genótipos de milho no Tocantins, Brasil. Revista Ciência Agronômica, v. 45, p. 856-862, 2014.

COMPANHIA NACIONAL DE ABASTECIMENTO. Acompanhamento de safra brasileira: grãos, safra 2015/16, quarto levantamento. Brasília, 2016. Disponível em: http://www. conab.gov.br/OlalaCMS/uploads/arquivos/16_01_12_14_17_ 16_boletim_graos_janeiro_2016.pdf. Acesso em: 21 jan. 2016.

CRUZ, C. C. et al. A cultura do milho. Sete Lagoas: Embrapa Milho e Sorgo, -, 2008. 517 p.

CRUZ, C. D. GENES: a software package for analysis in experimental statistics and quantitative genetics. Acta Scientiarum. Agronomy, v. 35, p. 271-276, 2013.

CRUZ, C. D.; CARNEIRO, P. C. S.; REGAZZI, A. J. Modelos biométricos aplicados ao melhoramento genético. 3. ed. Viçosa, MG: Editora UFV, 2014. 668 p.

DUARTE，J. B.; VENCOVSKY, R. Interação genótipos $\mathbf{x}$ ambientes: uma Introdução à análise AMMI. Ribeirão Preto: Sociedade Brasileira de Genética, 1999. 60 p.

EBERHART, S. A.; RUSSELL, W. A. Stability parameters for comparing varieties. Crop Science, v. 6, p. 36-40, 1966.

FRITSCHE-NETO, R. et al. Updating the ranking of the coefficients of variation from maize experiments. Acta Scientiarum. Agronomy, v. 34, p. 99-101, 2012.

GAUCH, H. G.; ZOBEL, R. W. AMMI analysis of yield trials. In: KANG, M. S.; GAUCH, H. G. (Ed.). Genotype-byenvironment proved and under what conditions this can be most environment interaction. Boca Raton, FL: CRC Press, p. 1-40. 1996.

HALDANE, J. B. S. The interaction of nature and nurture. Annals of Eugenics, v. 13, p. 197-205, 1946.

HALLAUER, A. R.; MIRANDA FILHO, J. B.; CARENA M. J. Quantitative genetics in maize breeding. New York: Springer, 2010. $663 \mathrm{p}$.

MALDANER, L. J. et al. Exigências agroclimáticas da cultura do milho (Zea mays). Revista Brasileira de Energia Renováveis, v. 3, p. 13-23, 2014.

MENDES, F. F. et al. Adaptability and stability of maize varieties using mixed model methodology. Crop Breeding and Applied Biotechnology, v. 12, n. 2, p. 111-117, 2012.

MIRANDA, G. V. et al. Multivariate analyses of genotype $\mathrm{x}$ environment interaction of popcorn. Pesquisa Agropecuária Brasileira, v. 44, n. 1, p. 45-50, 2009.

NAMORATO, H. et al. Comparing biplot multivariate analyses with Eberhart and Russell' method for genotype 
$\mathrm{x}$ environment interaction. Crop Breeding and Applied Biotechnology, v. 9, p. 299-307, 2009.

OLIVEIRA, R. B. R.; MOREIRA, R. M. P.; FERREIRA J. M. Adaptability and stability of maize landrace varieties. Semina: Ciências Agrárias, v. 34, n. 6, p. 2555-2564, 2013.

PIMENTEL-GOMES, F. Curso de estatística experimental. São Paulo: Nobel, 2000. 468 p.

R DEVELOPMENT CORE TEAM. R: a language and environment for statistical computing. Vienna, Austria: R Foundation for Statistical Computing, 2010.

RESENDE, M. D. V. O Software Selegen - REML/BLUP: sistema estatístico e seleção genética computadorizada via modelos lineares mistos. Colombo, PR: Embrapa Florestas, 2007. 359 p.

RESENDE, M. D. V.; DUARTE, J. B. Precisão e controle de qualidade em experimentos de avaliação de cultivares. Pesquisa Agropecuária Tropical, v. 37, p. 182-194, 2007.
RIOS, S. A. et al. Adaptability and stability of carotenoids in maize cultivars. Crop Breeding and Applied Biotechnology, v. 9, p. 313-319, 2009.

ROCHA, R. B. et al. Adaptabilidade e estabilidade da produção de café beneficiado em Coffea canéfora. Ciência Rural, v. 45, n. 9, p. 1531-1537, 2015.

SCAPIM, C. A. et al. Correlations between the stability and adaptability statistics of popcorn cultivars. Euphytica, v. 174, p. 209-218, 2010.

SILVA, G. O. et al. Verificação da adaptabilidade e estabilidade de populações de cenoura pelos métodos AMMI, GGE biplot e REML/BLUP. Bragantia, v. 70, n. 3, p. 494$501,2011$.

TORRES, F. E. et al. Interação genótipo x ambiente em genótipos de feijão-caupi semiprostrado via modelos mistos. Bragantia, v. 74, p. 255-260, 2015. 